\title{
Organizational Justice to Achieve Job Satisfaction for Social Workers in Youth Care
}

\section{Amr M. Abdel Hamied Mansour (PhD)}

Assistant Professor at Social Planning Department Faculty of Social Work- Helwan University- Cairo- Egypt.

Hossam M. Mohammed Ismail (PH. D)

Assistant Professor at Social Planning Department Faculty of Social Work- Helwan University- Cairo- Egypt. 


\section{Organizational Justice to Achieve Job Satisfaction for Social Workers in Youth Care}

\section{Amr M. Abdel Hamied Mansour (PhD)}

Assistant Professor at Social Planning Department

Faculty of Social Work- Helwan University- Cairo- Egypt.

\section{Hossam M. Mohammed Ismail (PH. D)}

Assistant Professor at Social Planning Department

Faculty of Social Work- Helwan University- Cairo- Egypt.

\section{Abstract:}

This study aims to determine the relationship between organizational justice and job satisfaction for social workers in the Youth Welfare Department at Helwan University.

Organizational justice is the basis for the survival and continuity of institutions, and for achieving outstanding performance by employees through the development of their potential, which is one of the most important elements in the institutional environment. This is not based on the physical and financial resources of the institution only because the productivity of organizations today relies on existing human resources, and the skills and abilities of these resources to continuously develop their performance.

The study was applied to (112) social workers in the Youth Care Department at Helwan University from the total population of all the social workers in the Youth Care Department at the university.

The study results indicate that there is a positive relationship of statistical significance at $(0.01)$ level between organizational justice and the job satisfaction of social workers in the youth care department. Keywords: Organizational Justice, Job Satisfaction, Social Workers in Youth Care Department.

Introduction:

Human resource is the cornerstone of the success and progress of organizations reflecting an individual's abilities, intellect, personal skills and the desire to work. Organizations should focus their efforts on the optimal use of human resources to achieve job satisfaction for employees through organizational justice. Organizational Justice is considered one of the basic components of an organization's social and psychological structure. Organizational justice focuses on managerial attention to employees' feelings and behavior which impact their performance and effectiveness (Miles, 2000, p.12). 
(Weiss, et. al 1999) study found that the perception of organizational justice impacted many important personal and organizational variables such as emotional responses to the individual, as well as individual performance and behaviors in the workplace. (Zwick \& Chen, 1999, pp. 688-699) research indicated that an organization would incur higher costs for regulatory justice, but that it was an investment guaranteeing the increasing effectiveness of the organization, ultimately achieving its long-term excellence.

The idea of organizational justice dates back to the theory of equity or equality presented by (Adam, 1963) which states that the individual's sense of fairness or not is determined by comparing the rate of his outputs to his inputs, with the rate of outputs and inputs of others. The result of that process has three cases: (Alwan, 2007, p. 59)

1. The individual's sense of equity and injustice when the result of comparison is in the form: Individual Outputs / Inputs = Outputs of a colleague / inputs - in this case, the individual is born with a sense of satisfaction and loyalty to his organization.

2. An individual's sense of unfairness when the result of comparison is in the form: Individual Outputs / Inputs > Outputs of a colleague / inputs - in this case, the individual harbours feelings of tension and uneasiness, which drives him to take action to alleviate it, thus affecting his ability to work and his loyalty to his organization.

3. The individual's sense of favoritism when the result of comparison is in the form of: Individual Outputs / Inputs < Outputs of a colleague / inputs - in this case, organizational justice is absent, showing favor for other members of the organization with arbitrariness and unfairness.

Therefore, organizational justice is the value resulting from the individual's perception of the integrity and objectivity of the procedures and returns in the institution in which he operates (Saud \& Sultan, 2009, p. 200).

Based on the above, it is clear that organizational justice contributes to the achievement of equality and integrity in the rights and duties of the individual and the organization. It also embodies the principle of realizing the obligations of the employees towards the organization in which they work and the organizational trust required between the parties (Albashabsha, 2008, P. 429).

Thus, organizational justice is one of the most important factors affecting the relations between the employee and the manager, the relations between colleagues, and the employee's relationship with the organization. Therefore, the employee's perception of organizational justice affects his relations with the organization, 
colleagues and managers (Khan, et al., 2010). In this context, attention to organizational justice contributes significantly to raising the level of performance of individuals because it provides the opportunity to generate ideas and build a bridge of trust between workers and management on the one hand, and between all workers on the other (Deesler, 2003, p. 75). Hence, writers and researchers in social and behavioral sciences have realized the importance of the value of organizational justice and its role in achieving satisfaction and good morale among employees, which is reflected positively in the improvement of performance within organizations. Whereas, workers' sense of injustice or inequality causes them to suffer from tension, frustration and alienation at work, which negatively affects performance and productivity (Al-Qaisi, 2010, p. 62).

The concept of organizational justice is divided into two main types: Distributive Justice, which refers to the fairness of the employee's outputs, and Procedural Justice, referring to the fairness of the procedures (the fairness of the procedures used to identify these outputs is recognized by some), some add a third type called Interactional Justice (Viswesvaran. et al., 1998, P365-371).

The study of (Mooreman et al., 2001) confirmed that procedural fairness is the cause of perceived organizational support, which mediates the relationship between procedural fairness and only three dimensions of organizational citizenship behavior, thus indirectly influencing the fairness of actions on organizational citizenship behavior and job satisfaction.

The results of (Schnake, et al., 2002) found that the organizational characteristics underlying organizational justice have the fundamental effect of recognizing the fairness of distribution, the fairness of procedures and the fairness of interactions. The organizational level also mediates the relationship between organizational characteristics and organizational justice dimensions. Organizational characteristics have a positive impact on organizational justice and are stronger at the lower organizational level and weaker at the higher organizational level.

The study by (Hassanein, 2004) also confirmed the existence of a positive and moral correlation between the dimensions of organizational justice in organizations, in addition to the significant impact of the dimensions of organizational justice on the dimensions of organizational commitment. 
The study of (Chang \& Liao, 2009) found that there is a significant effect on the extent to which employees perceive organizational justice depending on both job satisfaction and organizational commitment. It also indicates that differences in personal characteristics (age, marital status, years of experience, type of employment contract) have a significant impact on employees' perception of organizational justice as well as on both job satisfaction and organizational commitment. (Follger, 1998) argues that organizational justice is a moral behavior of virtue that dictates to employees how to interact and engage with one another (Croparzano, 2001, p.165) and contributes to the preservation of human resources in the organization (Ghanem, 2015, p. 338).

Scientists have divided the dimensions of organizational justice into three types: Distributive Justice, Procedural Justice, and Transactional Justice.

1. Distributive Justice: The concept of distributive justice reflects the sense of justice workers have of the outputs they receive in the form of wages, promotions and incentives for their work.

The current study shows that distributive justice refers to the individual's perception of the fairness of the outputs he makes and returns he receives when comparing himself to what others do and receive.

2. Procedural Justice relates to the fairness of the procedures used to convert inputs into outputs and the final outcomes obtained by workers. It also enables us to judge the rules and procedures applied in the organization in terms of impartiality and fairness. The degree of procedural justice is linked to the degree of mutual trust between the managers and employees; the greater trust amongst them, the more procedural justice workers felt (Quality, 2010, p. 311).

The current study refers to it as the extent to which social workers have the opportunity to express their views and feelings when formulating procedures, and their ability to influence the procedures used for the purposes of the distribution of outputs that determine the level of awareness of procedural justice.

3- Transactional Justice is concerned with the behavior of the organization's management when dealing with other staff. This type of justice shows the extent of employees' sense of fairness when dealing with the management of the organization in which they work and the justness of the transactions between them, which indicates the need for respect and reasonable behavior throughout all interactions 
between colleagues. The fairness of transactions relates to the extent to which the worker is aware of his relationship with the manager through being treated with respect and regard, and being able to discuss decisions that are strictly related to his job.

It is possible to say that the loss of any of the aforementioned dimensions, which explains organizational justice, leads to a feeling of unfairness, injustice and tension in an employee's behavior as well as a lack of job satisfaction. The fairness of transactions represents the method used in dealing with the individual and the fairness of the procedures represents the fairness of the policies and procedures used to determine the output received by the individual in the organization such as wages, promotions, additional benefits, etc. Comparison in the performance of the individual, in terms of quantity and quality, represents the outcome of several factors such as: effort, learning, experience, training, and others.

It follows from the above that organizational justice has become one of the most important variables that contributes to the development of the positive aims and attitudes of workers in order to achieve satisfaction in their jobs. Organizational variables that are affected by the level of organizational justice and job satisfaction, which was of great importance as one of the phenomena of organizational behavior.

It is confirmed by "Edwin Lock" that job satisfaction is the positive emotional state resulting from the individual's assessment of his or her job, and that this job satisfaction is achieved in the case where the individual comes out with a positive evaluation (Salah Eddin, 2001, p. 211). Job satisfaction reflects the psychological feeling of contentment, satisfaction, or happiness to satisfy needs, desires and expectations with the same work (job content), working environment, trust, loyalty, belonging to work, and other relevant factors and indicators (Hamid, 2014, p. 50).

Job satisfaction also contributes to an employee's acceptance of his work in all its aspects, namely the type of work, its requirements, its physical conditions, its social and economic status, and the human relations between the managers, colleagues and subordinates (Al-Khairi, 2008, p. 710). It also reflects the positive feelings they have towards their work. This work produces a material income and an opportunity for promotion, and an appreciation and place in the community (Kurdish, 1996, p. 313). Job satisfaction is not the outcome of a single factor, but is the result of the interaction of a 
set of factors that relate to the internal or external environment. Therefore, these factors are linked to the overall composition of the individual and the working environment, the more satisfied the basic needs are where a more positive attitude is had by the individual. This is confirmed by the study of (Lofty, 1993) which says that the social factors leading to satisfaction with work are friendship, belonging to informal working groups, feelings of security and stability, as well as material benefits such as wage increases, physical incentives, physical conditions of work, good social relations with colleagues, inclusion in the decision-making process within the organization, plus the supervisor's attention in solving the social and personal problems of the worker without concern for only solving the problems of work and production.

(Hamza's, 2004) study revealed a set of planning indicators on which to support the job satisfaction of social workers working in the educational field in different stages, in the Kingdom of Bahrain, related to the factors of experience and the manner of dealing with different situations in institutions.

The study of (Aweidah, 2008) confirmed the relationship between organizational loyalty and job satisfaction among employees in NGOs by identifying their job satisfaction indicators, such as satisfaction with management style, satisfaction with work colleagues, satisfaction with earnings, satisfaction with work environment, and self-satisfaction. It points out that employees who are satisfied when they are more productive than others do somewhat better than those who do not enjoy job satisfaction in their institutions and workplaces (Al Khaza'aleh, 2001, p. 396). Edward stressed that individuals with a high level of satisfaction are more productive at work than individuals with a low level of satisfaction, which reinforces the importance of that correlation between high satisfaction and outstanding job performance (Edward, 2009, p.p13-22).

The Field of university youth care is one of the most important areas for the practice of social service, where the profession seeks to strengthen the educational function of the university curriculum through the work of social workers in youth welfare agencies at different levels, activating the services provided by these agencies as well as the various services and programs for youth in universities (Ahmed, 2001, p. 1056). Social workers in youth care are the professional force responsible for carrying out their activities. Various approaches have been developed to benefit from these professional 
forces such as defining their roles and professional activities in the fields of social service practice, and emphasizing the need for competence, skill and organizational expertise (Meyer, 1976, p.p229231). These activities and services are provided by specialists who work at the progressive levels of youth welfare services and who have a range of technical, mental and behavioral skills to enable them to understand students and their behavior. This enables them to influence students and provide them with specialized professional advice. The team structure consists of social workers, athletes and technicians as well as supervision by faculty members of the university on the activities of the various committees (Abu al-Maati, 1999, p. 28). It was therefore necessary to determine the level of organizational justice dimensions of the social specialists in the departments of youth care at Helwan University to achieve their job satisfaction in order to ensure better professional performance rates in providing services, programs and activities for university youth, and strengthen the bridges of trust between them and the senior management and achieve some kind of job commitment within their work.

\section{Study Problem:}

After reviewing the literature that deals with the subject of the study, with reference to the theoretical heritage and conceptual framework directed to the study and reference to previous studies related to the subject of the study, the researchers concluded the Study Problem as the following issues:

1. What is the level of organizational justice felt by social workers in the youth care department?

2. What is the level of job satisfaction felt by social workers in the youth care department?

3. What is the relationship between organizational justice and job satisfaction for social workers in the youth care department?

4. Propose a set of planning indicators to increase the achievement of job satisfaction for social workers in the youth care department through organizational justice.

\section{Study Objectives:}

1. Determine the level of organizational justice felt by social workers in the youth care department.

2. Determine the level of job satisfaction felt by social workers in the youth care department 
3. Identify the most important dimensions of organizational justice to achieve job satisfaction for social workers in the youth care department

4. Determine the relationship between organizational justice and job satisfaction for social workers in the youth care department

Propose planning indicators to increase job satisfaction of social workers in the youth care department through organizational justice.

\section{Study Hypotheses:}

First hypothesis: "It is expected that the level of administrative justice amongst social workers in the Department of Youth Care is high". This hypothesis can be tested through the following indicators:

A) Distributive justice is equality in the distribution of incomes.

B) Procedural justice is equality of rights and duties.

C) Transactional justice equal opportunities are represented.

Second hypothesis: "It is expected that the level of the dimensions of job satisfaction for social workers in the Department of Youth Care is high". This hypothesis can be tested through the following indicators:
A) Satisfaction with the job.
B) Satisfaction with management style.
C) Satisfaction with colleagues at work.
D) Satisfaction with the return.
E) Satisfaction with the work environment.
F) Self-satisfaction.

Third hypothesis: "There is a statistically significant relationship between organizational justice and the achievement of job satisfaction for social workers in the Department of Youth Care."

\section{Concepts:}

\section{Organizational Justice Concept:}

Justice can be defined as "the sense of fairness and equity in the conduct between the staff and management of the organization."

Organizational justice is defined as "an important value, sense and awareness felt by the staff of the organization in the context of psychologically and administratively generated assessments making comparisons between mutual values obtained by the staff and the organization" (Gouda, 2010, p. 307).

According to "Newstrom \& Danis", organizational justice is based on the premise that "individuals tend to judge justice by comparing their inputs to the outputs they receive and also comparing their input-to-output ratio with other colleagues (Till, E., and Karren, R., 2011, p.p42-57). 


\section{Operational Definition of Organizational Justice in the study:}

Degree and level of distributive justice "equal distribution of income" and procedural justice "equality of rights and duties" and transactional justice "equal opportunities" followed by the university of social workers based in the department of youth care.

\section{Job Satisfaction Concept:}

"Hample" defines job satisfaction as reflecting the degree of congruence between the real returns that an individual receives and expects (Manawi, 1998, p. 122). "Stone" defines it as the state in which the individual integrates with his job and his work, or becomes a man who takes the job and interacts with it through his career ambition, his desire to grow and progress, and to achieve his social goals through it (Sultan, 2004, p. 196)"Loller" believes that job satisfaction is more likely to get the individual what he expected, making him more satisfied and fulfilled by feeling happy with the work itself and the work environment (Ashour, 1983, p. 53).

\section{Operational definition of Job Satisfaction in the study:}

Degree and level of satisfaction of the social workers in the Department of Youth Care at Helwan University regarding his job, management style, colleagues in work, return, work environment, himself.

\section{Theoretical framework: "Theory of justice for John Rawls"}

This theory is based on the concept of justice and equality, as well as on the concepts of social contracts and distributive justice. John Rawls focuses on the concept of equity in justice by demonstrating that individual rights can never be waived, and that the individual is an end in itself rather than a result (Iuod, 2007, p. 13).

True justice allows a society to rectify its inequities, with the end result yielding fairness to all its members. All social goods, liberty, power, opportunities, income, and wealth are to be equally distributed only if the unequal distribution of these goods favors the least advantaged members of a community. Rawls contends that the inequality of opportunity is permissible if it is advantageous to those who have been set aside. Rawls's theory proposes a minmax approach that essentially maximizes the place of the least advantaged. Using a concept he calls the "veil of ignorance," Rawls reasons that a just policy can be written only by those who cannot know how the policy will impact themselves. The dual beliefs that a transaction's result should be for the greater good and that advantages and set-asides for those who have been marginalized are appropriate reflect core social 
work values. Rawls's theory supports the development of a progressive and active welfare state (Colby, 2008, p. p 118-117).

Rawls derived two basic principles:

1. Each person is to have an equal right to the most extensive scheme of equal basic liberties compatible with a similar scheme of liberties for others;

2. Social and economic inequalities are to be arranged so that they are both (a) reasonably expected to be to everyone's advantage, and (b) attached to positions and offices open to all (Craig, 2002, p 670).

\section{Methodology:}

This study is a descriptive study that relies on the Comprehensive social survey method for social workers in Youth Care Departments, and applies to (112) social workers, the total population of all social workers in the Youth Care Department at Helwan University, during the period from 1/10/2018 to 3/12/2018.

The researchers designed a tool questionnaire for social workers by reference to a theoretical framework and related studies, as well as utilizing some of the standards and questionnaire forms related to measure the dimensions of organizational justice, and measure the dimensions of job satisfaction for social workers and finding the correlation between two variables. The validity of the tool was confirmed after it was presented to (5) experts, social work professors in the Faculty of Social Work, Helwan University. The statistical reliability of a sample of (10) vocabulary of social workers using the Alpha-Cronbach coefficient was also determined and the reliability coefficient (0.91) was reached, which is suitable for statistical reliability.

\section{Description of the study tool:}

\section{Table(1) Measuring the Dimensions of Organizational justice}

\begin{tabular}{||c||c||}
\hline \multicolumn{1}{|c||}{ Dimensions } & $\begin{array}{c}\text { Number } \\
\text { of Phrases }\end{array}$ \\
\hline \hline $\begin{array}{l}\text { First Dimension: Transactional justice = Equal } \\
\text { opportunities are represented }\end{array}$ & 7 \\
\hline \hline Second Dimension: Procedural justice = Equality of rights & 8 \\
\hline \hline Third Dimension: Procedural justice = Equality of duties & 8 \\
\hline \hline $\begin{array}{l}\text { Four Dimension: Distributive justice = Equality in the } \\
\text { distribution of incomes }\end{array}$ & 7 \\
\hline \hline Total & 30 \\
\hline
\end{tabular}




\begin{tabular}{||lcc|}
\hline \hline Egyptian Journal of Social Work (EJSW) & http://ejsw.journals.ekb.eg \\
Print ISSN: 2356-9204 & Online ISSN: 2356-9212 & Vol 8, Issue 1, June 2019 \\
\hline
\end{tabular}

Table (2) Measuring the Dimensions of job satisfaction

\begin{tabular}{||l||c||}
\hline \multicolumn{1}{|c|}{ Dimensions } & $\begin{array}{c}\text { Number } \\
\text { of Phrases }\end{array}$ \\
\hline \hline First Dimension: Satisfaction with the job & 9 \\
\hline \hline Second Dimension: Satisfaction with management style & 9 \\
\hline \hline Third Dimension: Satisfaction with colleagues at work & 8 \\
\hline \hline Four Dimension: Satisfaction with the return & 7 \\
\hline \hline Five Dimension: Satisfaction with the work environment & 6 \\
\hline \hline Six Dimension: Satisfaction with himself & 6 \\
\hline \hline Total & 45 \\
\hline
\end{tabular}

\section{Table (3) Levels of arithmetic mean}

\begin{tabular}{||l||c||}
\hline \hline $\begin{array}{l}\text { If the average value of a phrase or dimension varies from } 1 \\
\text { to less than } 1.67\end{array}$ & low level \\
\hline \hline $\begin{array}{l}\text { If the average value of a phrase or dimension ranges from } \\
1.67 \text { to less than } 2.35\end{array}$ & $\begin{array}{c}\text { Average } \\
\text { level }\end{array}$ \\
\hline \hline $\begin{array}{l}\text { If the average value of the phrase or dimension varies from } \\
2.35 \text { to } 3\end{array}$ & $\begin{array}{c}\text { High } \\
\text { level }\end{array}$ \\
\hline
\end{tabular}

\section{Results of the field study:}

The first axis: Description of social workers in the study community:

Table (4) Description of social workers in the study community ( $N$ =112)

\begin{tabular}{|c|c|c|c|}
\hline $\mathrm{sr}$ & Quantitative variables & SMA & $\begin{array}{l}\text { Standard } \\
\text { Deviation }\end{array}$ \\
\hline 1 & Age & 36 & 7 \\
\hline 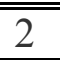 & Y Years of work experience & 10 & 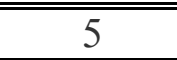 \\
\hline 3 & $\begin{array}{l}\text { Average monthly income of } \\
\text { the family }\end{array}$ & 1880 & 406 \\
\hline $\mathrm{Sr}$ & Gender & $\mathrm{X}$ & $\%$ \\
\hline 1 & Male & 60 & 53.6 \\
\hline 2 & Female & 52 & 46.4 \\
\hline \multicolumn{2}{|r|}{ Total } & 112 & 100 \\
\hline $\mathrm{Sr}$ & Qualification & $\overline{\mathrm{X}}$ & 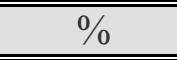 \\
\hline 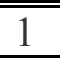 & Bachelor's degree & 97 & 86.6 \\
\hline 2 & M.A. & 7 & 6.3 \\
\hline 3 & Ph.D. & 8 & 7.1 \\
\hline \multicolumn{2}{|r|}{ Total } & 112 & 100 \\
\hline
\end{tabular}




\begin{tabular}{||lcc||}
\hline \multicolumn{2}{|l|}{ Egyptian Journal of Social Work (EJSW) } & http://ejsw.journals.ekb.eg \\
Print ISSN: 2356-9204 & Online ISSN: 2356-9212 & Vol 8, Issue 1, June 2019 \\
\hline \hline
\end{tabular}

\begin{tabular}{|c|c|c|c|}
\hline $\mathrm{Sr}$ & Job & $\mathrm{X}$ & $\%$ \\
\hline 1 & Director of the Department & 1 & 0.9 \\
\hline 2 & Head of the Department & 10 & 8.9 \\
\hline 3 & Social worker & 101 & 90.2 \\
\hline \multicolumn{2}{|r|}{ Total } & 112 & 100 \\
\hline
\end{tabular}

The above table shows that the average age of social workers is 36 years, with a standard deviation of approximately (7) years, the average number of years of experience in the field of work is 10 years, with a standard deviation of approximately (5) years, the average monthly income was (1880) pounds, with a standard deviation of (406) pounds.

The highest proportion of social workers were male (53.6\%), with females representing $(46.4 \%)$. The highest percentage of social workers had Bachelor's degree $(86.6 \%)$, next were $\mathrm{PhD}$ holders $(7.1 \%)$. The largest percentage of workers are working as social workers $(90.2 \%)$, with head of department at $(8.9 \%)$ and director of management $(0.9 \%)$. This may reflect wage differences among state employees and may affect the level of labor.

The proportion of males being larger than females may be due to the nature of the work in the field of youth care which requires more dependence on males. However, we need to empower women in the field of youth care. The percentage of those with high qualifications may be due to the interest of the state and its observance of degrees in appointments and career advancement and to increase the proportion of social workers as the basis for implementing youth care plans and programs.

\section{Test Study hypothesis:}

(1) Test first hypothesis: "It is expected that the level of administrative justice amongst social workers in the Department of Youth Care is high". 
Table (5) The level of Organizational justice dimensions of social workers in the Youth Care Department $(\mathrm{N}=112)$

\begin{tabular}{|c|c|c|c|c|c|}
\hline $\mathrm{Sr}$ & Dimensions & SMA & $\begin{array}{l}\text { Standard } \\
\text { Deviation }\end{array}$ & Level & Ranking \\
\hline 1 & \begin{tabular}{|l} 
Transactional justice $=$ Equa \\
opportunities are represented
\end{tabular} & 2.55 & 0.48 & High & 1 \\
\hline 2 & $\begin{array}{c}\text { Procedural justice }=\text { Equality } \\
\text { of rights }\end{array}$ & 2.4 & 0.41 & High & 2 \\
\hline 3 & $\begin{array}{c}\text { Procedural justice }=\text { Equality } \\
\text { of duties }\end{array}$ & 2.15 & 0.3 & Average & 4 \\
\hline 4 & $\begin{array}{c}\text { Distributive justice }= \\
\text { Equality in the distribution } \\
\text { of incomes }\end{array}$ & 2.35 & 0.4 & High & 3 \\
\hline & $\begin{array}{l}\text { The Dimensions of } \\
\text { ganizational justice as a whole }\end{array}$ & 2.36 & 0.32 & \multicolumn{2}{|c|}{ High level } \\
\hline
\end{tabular}

The above table shows that the dimensions of organizational justice for social workers in the Youth Care Department were as follows: The first rank was equal to the opportunities available at an average of (2.55). Second were equal rights which were equal to an arithmetic mean of (2.4). In the distribution of incomes was an average of (2.35). Fourth ranked the equality of duties with (2.15). The results show that the average of the organizational justice dimensions of social workers in the youth care field was (2.36), taking into account the variables of justice. This is what the result of the study of (Hassanein, 2004) and (Schminke, et al. 2002), which accepts the first hypothesis of the study; "It is expected that the level of administrative justice amongst social workers in the Department of Youth Care is high".

(2-1) Test second hypothesis: "It is expected that the level of the dimensions of job satisfaction for social workers in the Department of Youth Care is high." 
Table (6): The level of the dimensions of job satisfaction for social workers in the Youth Care Department $(\mathrm{N}=112)$

\begin{tabular}{|c|c|c|c|c|c|}
\hline $\mathrm{Sr}$ & Dimensions & SMA & $\begin{array}{l}\text { Standard } \\
\text { Deviation }\end{array}$ & Level & Ranking \\
\hline 1 & $\begin{array}{l}\text { Satisfaction with the } \\
\text { job }\end{array}$ & 2.64 & 0.39 & High & 2 \\
\hline 2 & $\begin{array}{c}\text { Satisfaction with } \\
\text { management style }\end{array}$ & 2.51 & 0.38 & High & 3 \\
\hline 3 & $\begin{array}{c}\text { Satisfaction with } \\
\text { colleagues at work }\end{array}$ & 2.77 & 0.32 & High & 1 \\
\hline 4 & $\begin{array}{l}\text { Satisfaction with the } \\
\text { return }\end{array}$ & 2.14 & 0.52 & Average & 6 \\
\hline 5 & $\begin{array}{c}\text { Satisfaction with the } \\
\text { work environment }\end{array}$ & 2.49 & 0.58 & $\overline{\text { High }}$ & 4 \\
\hline 6 & $\begin{array}{l}\text { Satisfaction with } \\
\text { himself }\end{array}$ & 2.47 & 0.31 & High & 5 \\
\hline & $\begin{array}{l}\text { e Dimensions of job } \\
\text { isfaction as a whole }\end{array}$ & 2.5 & 0.32 & \multicolumn{2}{|c|}{ High level } \\
\hline
\end{tabular}

The table above shows that the job satisfaction of social workers in the Youth Care Department was as follows: Ranked first was the satisfaction with work colleagues, with an average of (2.77). Second was satisfaction with the job, with an average of (2.64). Third was satisfaction with management style, with an average of (2.51), fourth was satisfaction with the work environment, with an average of (2.49), fifth was self-satisfaction at (2.47), and the sixth was satisfaction with the return, with the mean of (2.14). The table shows that the average dimensions of job satisfaction for social workers was (2.5), which is a high rate. This may reflect the interest of officials in achieving satisfaction for social workers to ensure that the results and outputs of their work are effective, which will impact the effectiveness of programs, services and activities provided to university youth. This is what the study of (Khaza'aleh, 2001) and (Aweida, 2008) confirmed. This accepts the second hypothesis of the study that "the level of the dimensions of job satisfaction for social workers in the Department of Youth Care is high." 
(3-1) Test third hypothesis: "There is a statistically significant relationship between organizational justice and job satisfaction for social workers in the Youth Care Department":

\section{Table (7) Relationship between Organizational Justice and Job}

Satisfaction of Social Workers in the Youth Care Department

$(\mathrm{N}=112)$

\begin{tabular}{|c|c|c|c|c|c|c|c|c|}
\hline $\mathrm{Sr}$ & Dimension & 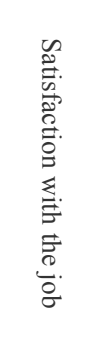 & 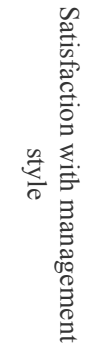 & 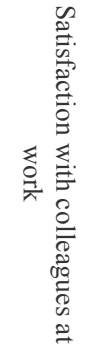 & 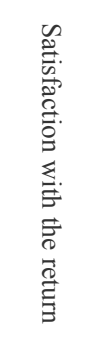 & 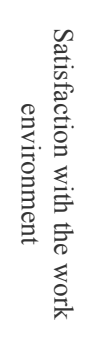 & 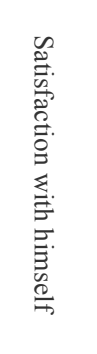 & 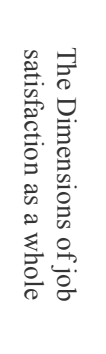 \\
\hline 1 & $\begin{array}{c}\text { Equal } \\
\text { opportunities } \\
\text { are represented }\end{array}$ & $* * 0.721$ & $* * 0.594$ & $* * 0.282$ & $* * 0.763$ & $* * 0.722$ & 0.108 & $* * 0.749$ \\
\hline 2 & $\begin{array}{c}\begin{array}{c}\text { Equality of } \\
\text { rights }\end{array} \\
\end{array}$ & $* * 0.689$ & $* * 0.682$ & $* * 0.278$ & $* * 0.752$ & $* * 0.775$ & $* 0.217$ & $* * 0.789$ \\
\hline 3 & $\begin{array}{c}\text { Equality of } \\
\text { duties }\end{array}$ & $* * 0.472$ & $* * 0.531$ & $* * 0.327$ & $* * 0.271$ & $* * 0.357$ & $* * 0.345$ & $* * 0.490$ \\
\hline 4 & $\begin{array}{l}\text { Equality in the } \\
\text { distribution of } \\
\text { incomes }\end{array}$ & $* * 0.377$ & $* * 0.617$ & $* * 0.246$ & $* * 0.369$ & $* * 0.508$ & 0.083 & $* * 0.504$ \\
\hline & $\begin{array}{l}\text { Dimensions of } \\
\text { rganizational } \\
\text { tice as a whole }\end{array}$ & $* * 0.718$ & $* * 0.757$ & $* * 0.348$ & $* * 0.704$ & $* * 0.759$ & $* 0.216$ & $* * 0.804$ \\
\hline
\end{tabular}

Significant at $(0.01)^{*}$

Significant at $(0.05)^{* *}$

The above table shows that there is a statistically significant correlation between the level of organizational justice and the achievement of job satisfaction for social workers in the Youth Care Department. The most important dimensions of organizational justice to achieve job satisfaction for social workers in the Youth Care Department are: equality of rights, equality of opportunity, followed by equal distribution of income and, finally, equal duties. This may be due to the strong correlation between these variables and the fact that they reflect what the study aims to achieve. This may reflect that organizational justice is one of the main motives for achieving job satisfaction, since the more equitable the procedures are, the more equal the rights, thus improving their performance and enabling them to practice their work, and achieve the targeted results (Chang\& Liao, 2009). This accepts the third hypothesis of the study, which is "there is a positive relationship statistically significant between organizational 
justice and the achievement of job satisfaction of social workers in the Youth Care Department."

Table (8) Analysis of the simple regression of the relationship between organizational justice and job satisfaction of social workers in Youth Care Department $(\mathrm{N}=112)$

\begin{tabular}{|c|c|c|c|c|c|c|c|c|}
\hline \multirow{2}{*}{ 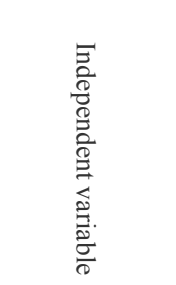 } & \multirow{2}{*}{ 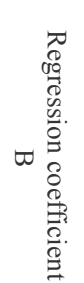 } & \multicolumn{2}{|c|}{ T-Test } & \multicolumn{2}{|c|}{ F-Test } & \multicolumn{2}{|c|}{$\begin{array}{c}\text { Coefficient of correlation } \\
\text { R }\end{array}$} & \multirow{2}{*}{ 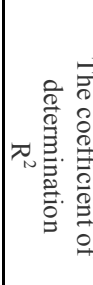 } \\
\hline & & 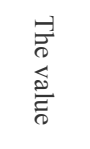 & $\begin{array}{l}3 \\
\frac{3}{0} \\
\text { 苞 }\end{array}$ & 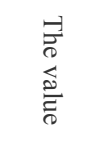 & $\begin{array}{l}3 \\
\frac{3}{20} \\
\text { E. }\end{array}$ & 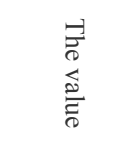 & 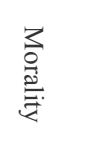 & \\
\hline $\begin{array}{l}\text { organizational } \\
\text { justice }\end{array}$ & 0.810 & 14.172 & 0.00 & 200.835 & 0.00 & 0.804 & 0.00 & 0.646 \\
\hline
\end{tabular}

The above table shows the correlation coefficient between the independent variable "organizational justice" and the dependent variable "job satisfaction of social workers in the Youth Care Department" (0.804), which is statistically significant at 0.01 level. The result of the test $(F=200.835, \mathrm{Sig}=0.000)$ indicates the significance of the regression model, and the value of the coefficient of determination (0.646), meaning that the organizational justice interprets $(64.6 \%)$ of the changes in the job satisfaction of social workers in the Youth Care Department. The value of the regression coefficient (0.810), indicating a positive relationship between the variable $(T=14.172, \mathrm{Sig}=0.000)$, indicates that the effect of the independent variable on the dependent variable is statistically significant at a level of (0.01), which accepts the third hypothesis of the study that " there is a statistically significant relationship between organizational justice and the achievement of job satisfaction for social workers in the Department of Youth Care."

\section{Discussion:}

The results of the study showed that the level of organizational justice for social workers in the youth care department is high. This may reflect the university's tendency to adopt new policies in which equal opportunities exist between all employees, allowing them to benefit from the services the university provides through clear criteria for good governance. This eliminates exceptions, mediation, favoritism and the absence of criteria for eligibility, as well as achieving justice in the distribution of income between social workers and their colleagues. Therefore, there are no differences in the 
physical and social gap layer, nor marginalized and socially excluded, which negatively affects the performance of the target professional work and output, which is consistent with the study (Weiss, et all, 1999). The results showed that the impact of the individual's perception of organizational justice is based on important organizational and personal variables and has a significant impact on his professional performance within his work. It also shows that the level of job satisfaction among social workers in the youth care department is high. This is in line with the study of (Hamza's, 2004) and the study of (Lofty, 1993), which confirm that the availability of organizational justice and participation in decision-making and relations between the employee and management, and with colleagues and social relations prevailing, contribute significantly to the satisfaction of employees. It is found through the current study in the existence of a statistically significant relationship between organizational justice and satisfaction of social workers in the youth care department. This may be due to the fact that organizational justice is the basis for achieving job satisfaction as it is one of the basic values guiding professional work and it is an ideal situation in which workers have the same rights and responsibilities. Also, the fair distribution of income and opportunities available, which are the real bridge to achieving job satisfaction among social workers working in youth care departments, agreed with the result of the (Chang \& Liao, 2009) study which emphasized that the individual's perception of organizational justice affects his / her functional satisfaction.

The study of (Mooreman et al., 2001) differed and indicated that the fairness of procedures has an indirect effect on organizational citizenship and satisfaction. We find that this conclusion was confirmed by John Rawals' principle in his theory of justice, "liberal equality", of the need to establish a just society based on justice and equity, in which all individuals enjoy equality without distinction of one category, and that there is the so-called veil of ignorance that is no one knows his place in society, his position or his social status or his gender. The theory is based on two principles of justice within institutions through the use of procedural justice as follows:- 


\section{Principle 1: (Priority of Freedom)}

Everyone has an equal right to the most comprehensive system of expansion of fundamental freedoms, equal to a symmetrical system of freedom for all.

\section{Principle 2: (the priority of justice on efficiency and welfare)}

Economic and social inequalities must be arranged to achieve both:

(A) The maximum benefit of the less beneficial, consistent with the principle of equitable saving.

(B) Make positions and positions open to all under equal opportunity equal opportunity conditions.

This means that all are equal in opportunities and need to provide equal treatment and reform bias towards individuals working for the development of their abilities and functional potential through a fair way through which social institutions can determine the basic rights and duties of the employees of the organization and the division of social and economic benefits on workers for further excellence And creativity at work.

\section{Planning Indicators to increase job satisfaction for social workers} in the Youth Care Department through organizational justice:

1. Necessity to pay attention to the development of the sense of employees' regulatory justice and its association with the components of job satisfaction.

\section{This is achieved through:}

A. ensuring fairness in the distribution of bonuses among employees by providing training courses for managers to enhance their understanding of the merits of awarding bonuses.

B. following clear, objective procedures when making decisions concerning the allocation of bonuses and evaluating the performance of the employees, according to the managers who implement them, and taking into consideration the interests of all parties affected by them.

C. holding induction sessions for employees to clarify the basis of performance evaluation procedures and the distribution of the rewards to them, putting pressure on managers to apply performance evaluation procedures and distribute rewards fairly.

D. the keenness of leaders on justice in dealing with all subordinates in the framework of respect, appreciation and justice in providing information and explanations related to subordinates. 
E. providing employees with a sense of care and attention, to inform them that they are part of the organization's inseparable entity, and to create opportunities for the participation of decision-making and opinion-giving personnel.

2. Necessity to provide the appropriate organizational climate, which contributes to reducing employees' feelings of dissatisfaction, due to the implications of achieving organizational justice and the development of functional performance through:

A. establishing clear criteria for promotion, performance evaluation and other important job-related activities.

B. granting the same benefits as permanent employees to temporary employees, where wages, opportunities for promotion and other important benefits can reduce their sense of dissatisfaction.

C. conducting induction courses for new employees and introducing them to the nature and potential of temporary jobs.

D. allowing workers to freely express and submit proposals and complaints.

3. Set rules that contribute to the development of organizational justice in order to achieve greater job satisfaction. For example:

A. Increased attention to human resources policies and the development of human relations;

B. Encouraging participation in the decision-making process, allowing employees to submit proposals, reviewing them and announcing changes to the employees, in order to increase self-satisfaction.

C. Introducing training programs to develop the abilities and skills of employees and working to provide equal opportunity for all employees.

D. Investigate procedural justice in dealing with individuals, whether in wages, in material rewards, in benefits, or in social and moral services.

E. The example set by administrative leaders of their positive behavior and interaction with their subordinates, becoming the cornerstone of employees' understanding of the many dimensions of satisfaction with style of management.

F. Taking into account the distribution of the functional burdens on individuals in a fair and appropriate manner, and informing individuals of what is required of them, in order to achieve satisfaction with the work environment. 
G. Building relations between officials and individuals on trust and openness and providing the opportunity for formal and informal communication, increasing the interaction of individuals and pushing them to work and productivity in order to achieve satisfaction with the job as a whole.

\section{References:}

- Abu Al-Maati, Maher, (1999), a conceptual framework for the development of youth care, a paper presented in the Journal of Studies in Social Work and Human Sciences, Faculty of Social Work, Helwan University, April.

- Ahmed, Tomader Mustafa, (2001), Professional skills of the social worker organized in the care of youth at the faculties of Helwan University, research published at the 11th Annual Conference, Faculty of Social Work, Cairo University, Fayoum Branch, p.

- Al-Khairi, Hussein, (2008), Job satisfaction and motivation for achievement in a sample of mentors in the general education stages in Al-Layth and Al-Qunfudah governorates, unpublished master's thesis, Faculty of Education, Umm Al-Qura University.

- Al-Manawi, Aisha Mustafa, (1998), Consumer Behavior, Cairo, I2, Ain Shams Library.

- Al-Qaisi, Hanaa, (2010), Educational Administration - Principles Theories - Modern Trends, Amman, Jordan, Dar Almanahaj Publishing and Distribution.

- Alwan, Qassim Nayef, (2007), The Effect of Organizational Justice on the Spread of Administrative Corruption, Journal of Economic Sciences and Sciences, Al-Tahiri University, Libya, Issue (7).

- Ashour, Ahmed Sakr, (1983), General Human Resources Department, Alexandria, Dar al-Maarifa University.

- Aweida, Ehab Ahmad, (2008), The Effect of Job Satisfaction among Employees in NGOs in Gaza Governorates, Unpublished Master Thesis, Islamic University, Gaza.

- Ayud, Omaima, (2007), New Liberalism, Cairo, International Center for Futures and Strategic Studies, No. (25).

- Bashaabsha Samer Abdel Majeed, (2008), The Impact of Organizational Justice on the Formation of Organizational Symmetry in Jordanian Public Institutions, Jordanian Journal of Business Administration, University of Jordan, Vol. 4, No. (4).

- Chang, Cheng-Ping, and Liao, I-Fei, (2009), "Individual Characteristics، Organizational Justice and Job Attitudes of Employees under Non- Standard Work Arrangements: Study of Employees of International Study of Employees of International Tourist Hotels", International Journal of Management, Vol. 26, No (2).

- Colby, Ira C, \& Dulmus, N., Catherine, and Sower, M., Karen, 
(2008), Comprehensive Handbook of Social Work and Social Welfare, social policy and policy practice, John Wiley \& sons Inc., v (4), New Jersey.

- Craig, Gary, (2002), Social Work and Social Justice, British Journal of Social Work, British Association of Social Workers.

- Dessler, Gary, (2003), Human Resources Management, translated by Mohammed Saied Abdel Muttal and Abdul Mohsen Gouda (Riyadh, Saudi Arabia, Dar Al-Marikh for publication.

- Edward, M, (2009), Success and Causality in sport, The influences of perception, Journal of sport Psychology, Vol 11, No (1).

- El Saud Ratep\& Sultan Suzan, (2009), The Degree of Organizational Justice in the Heads of Academic Departments in the Official Jordanian Universities and their Relation to the Organizational Loyalty of the Members of their Training Bodies, Damascus University Journal, Volume (25).

- Ghanem Fathallah Ahmed, (2015), The Palestinian Telecommunications Company's Practices in Preserving Human Resources and its Role in Enhancing the Functioning of Employees, AlAqsa University Journal, Human Sciences Series, Volume 19, No. (1).

- Gouda Mahfouz Ahmed, (2010), Human Resource Management, Dar Wael Publishing and Distribution, Amman.

- Hamid Baja, (2014), Master Thesis The role of motivation in achieving job satisfaction, University of Nizwa, College of Business Administration, Saudi Arabia.

- Hamza, Ahmed Ibrahim, (2004), determinants of job satisfaction of social workers in the light of some social and professional variables, research published at the 17th International Conference, Faculty of Social Work, Helwan University, March 2004.

- Hassanein, Gad Abdul-Samiea, (2004), "The Effect of Employees' Awareness of Organizational Regime on Organizational Commitment: An Empirical Study", Journal of Commercial Research, Volume 26, No. (2), Zagazig University, Faculty of Commerce.

- Khan, S., Mukhtar, S., and Niazi, M.A.K., (2010), "Link between Organizational Justice and Employee job Performance in the Work Place", Interdisciplinary Journal of Contemporary Research in Business, Vol (2), No (3).

- Khaza'aleh, Muhammad Salman, (2001), Satisfaction of Educational Supervisors, Principals and Teachers on the Implementation of Educational Supervision in Mafraq Governorate, Unpublished Master Thesis, Al-Bayt University, Jordan.

- Kurdi, Esmat Darwish, (1996), Job Satisfaction among Workers in Sports Activity in Jordanian Public and Private Universities, Journal of Educational Sciences Studies, Volume (32). 
- Lofty, Talaat Ibrahim, (1993), "Human Relations and Work Satisfaction", Journal of Social Work, Egyptian Association of Social Workers in Cairo, June, No. (37).

- Miles, A.J. (2000), "The cumulative Effects of justice perceptions", The Journal of Behavioral and Applied Management, Vol. (2) No. (1).

- Morrman, Robert H., \& Blakely, L. Gerald, and Niehoff, P., Brian, (2001) "Does perceived organizational support mediate the relationship between procedural justice and organizational citizenship behavior?" Academy of management journal, Vol.44.

- Salah Eden Ibrahim, (2001), Organizational Behavior, Alexandria, University House, First Edition.

- Schnake, M., \& Cochran, Dan, and Dumler, Mike, (2002) "Encouraging organizational citizenship: "The Effects of job satisfaction. Perceived Equity, and leadership", journal of managerial Issues, Vol. 7, No. (2).

- Sultan, Muhammad Saeed, (2004), Human Behavior in Organizations, Alexandria, New University House.

- Till, E., and Karren, R., (2011), Organizational Justice Perceptions and Pay Level satisfaction, Journal of Managerial Psychology, Vol (26), No (1).

- Viswesvaran, C., Deshperade S. \& Joseph J., (1998) "Job Satisfaction as a function of top management support for ethical behavior: A study of Indian youngers", Journal of Business Ethics, Vol.17.

- Weiss, Howard, M., \& Suckow, Kathleen and Cropanzano, Russell, (1999), "Effects of Justice conditions on Discrete Emotions", Journal of Applied Psychology, Vol, 84, No. (5).

- Zwick, R. \& Chen, Z.P., (1999), "What is the price of Fairness: H Bargaining study", Journal of Management, Vol. 25, No (6). 